\title{
Characterization of X-Disease Phytoplasmas in Chokecherry from North Dakota by PCR-RFLP and Sequence Analysis of the rRNA Gene Region
}

\author{
Y. H. Guo and Z.-M. Cheng, Department of Plant Sciences, and J. A. Walla, Department of Plant Pathology, \\ North Dakota State University, Fargo 58105
}

\begin{abstract}
Guo, Y. H., Cheng, Z.-M., and Walla, J. A. 2000. Characterization of X-disease phytoplasmas in chokecherry from North Dakota by PCR-RFLP and sequence analysis of the rRNA gene region. Plant Dis. 84:1235-1240.

Genetic variation of X-disease phytoplasma strains from chokecherry (ChX) in North Dakota and nearby sites, and their relatedness with three standard strains of the X-disease phytoplasma group, eastern X-disease (CX), western X-disease (WX), and goldenrod yellows (GR1) phytoplasmas, were studied. Primer pairs were developed to amplify the 23S ribosomal RNA (rRNA) gene and the 16S/23S spacer region. The rRNA genes (16S rRNA, 23S rRNA, and two ribosomal protein [rp] genes) and the $16 \mathrm{~S} / 23 \mathrm{~S}$ spacer region were amplified by polymerase chain reactions. The restriction fragment length polymorphism (RFLP) patterns of 16S rRNA, 23S rRNA, and rp genes, generated by digestion with four restriction enzymes (AluI, HpaII, MseI, and $R s a \mathrm{I}$ ), showed no difference among $43 \mathrm{ChX}$ phytoplasma isolates. Sequencing of the 441-bp $16 \mathrm{~S} / 23 \mathrm{~S}$ spacer region revealed variation at four positions among $12 \mathrm{ChX}$ phytoplasma strains. A tRNA ${ }^{\text {Ile }}$ and other conserved sequences were identified in the spacer region. Among X-disease subgroups, RFLP analysis indicated that $\mathrm{ChX}$ is similar to WX, closely related to CX, and easily distinguished from GR1. Sequencing indicated that $\mathrm{ChX}$ is closer to CX than to WX. Together, the analyses indicated that $\mathrm{ChX}$ phytoplasmas are genetically different from the standard strains of other X-disease phytoplasma subgroups.
\end{abstract}

Recent research on phytoplasmas (formerly known as mycoplasma-like organisms) and phytoplasma-associated diseases has focused on the development of techniques for detection of the organisms and diagnosis of their associated diseases. Such techniques include assays with antibodies $(15,25)$, genomic DNA probes (16), and, more recently, polymerase chain reaction (PCR)-based DNA markers (1). Other focal areas of phytoplasma research have been genetic variation among phytoplasmas and phylogenic relationships among phytoplasma groups and other mollicutes. Using heterogeneous DNA probes and differential screening, the $16 \mathrm{~S}$ ribosomal RNA (rRNA) gene and ribosomal protein (rp) genes have been cloned from a phytoplasma $(23,24)$. Based on the sequence of the $16 \mathrm{~S}$ rRNA gene, universal primers were designed and used to amplify $16 \mathrm{~S}$ rRNA gene segments from each known phytoplasma group. Restriction fragment length polymorphism (RFLP) analysis of PCR-amplified 16S rRNA and rp genes has

Corresponding author: Z.-M. Cheng

E-mail: zcheng@plains.nodak.edu

This research was supported by USDA-NRICGP grant 1999-2510.

Accepted for publication 8 August 2000.

Publication no. D-2000-0919-02R

(c) 2000 The American Phytopathological Society been used to differentiate phytoplasma groups $(4,20)$. Overall classification of phytoplasmas and general phylogenic relationships were derived from extensive studies of those conserved genes (10).

In contrast to the effort devoted to differentiating phytoplasmas among groups, limited work has been done on variation of phytoplasmas within groups or subgroups, or on host-pathogen interactions and host resistance. Such information is required to properly develop host resistance. Variation of phytoplasmas within groups has recently been described for ash yellows and elm yellows phytoplasmas $(8,9)$. Complimentary information regarding pathogen aggressiveness and host resistance has also been obtained for the ash yellows phytoplasma-green ash pathosystem $(30,31)$. Methods used to examine variability within phytoplasma groups have included those that have been used to examine variability among groups (i.e., PCR, RFLP, and sequencing analysis of 16S rRNA genes, rp genes, and the $16 \mathrm{~S} / 23 \mathrm{~S}$ spacer region).

$\mathrm{X}$-disease phytoplasmas are associated with one of the major stone fruit diseases in North America $(7,28)$. Two strains of the pathogen, eastern (Canadian peach) Xdisease (CX) and western X-disease (WX) phytoplasmas, were differentiated based on their geographic distribution, host range, and vectors $(28,33)$. The association of Xdisease phytoplasmas with X-disease symptoms in chokecherry $(\mathrm{ChX})$ in the north-central United States, (long called western X-disease) has been confirmed recently (13). Recent studies $(11,13)$ indicated that $\mathrm{ChX}$ phytoplasmas are closely related to CX and WX. However, only a limited number of isolates were used and little is known about genetic variation in $\mathrm{X}$-disease phytoplasmas; therefore, the relatedness of $\mathrm{ChX}$ to $\mathrm{CX}$ or WX phytoplasmas is uncertain. Information on genetic variation would allow selection of divergent isolates for studying host-pathogen interactions when variation on phytoplasma pathogenicity is unavailable. If phytoplasma isolates are generally uniform, one or a few random isolates may be sufficient in such studies.

The objectives of this study were to (i) characterize and assess genetic variability within ChX phytoplasma isolates from North Dakota by RFLP analysis of PCRamplified 16S rRNA, 23S rRNA, and rp genes and by sequence comparison of the spacer region of the $16 \mathrm{~S}$ and $23 \mathrm{~S}$ rRNA genes; and (ii) determine the genetic relatedness of ChX phytoplasmas to CX and WX phytoplasmas.

\section{MATERIALS AND METHODS}

Phytoplasma collection and DNA extraction. Forty-three chokecherry samples with X-disease symptoms were collected from sites across North Dakota and in adjacent Minnesota and Saskatchewan, Canada (Table 1). Two to four young shoots with leaves were collected from each plant in August. Each sample was placed in a plastic bag with a moist towel and stored at $4^{\circ} \mathrm{C}$ until DNA extraction. Chokecherry plants grown from seeds in a greenhouse were used as healthy controls. CX, WX, and goldenrod yellows (GR1) phytoplasma strains (one of each) were provided in periwinkles (Catharanthus roseus (L.) G. Don) by T. A. Chen (Rutgers University, New Brunswick, NJ), W. A. Sinclair (Cornell University, Ithaca, NY), and I.-M. Lee (USDA-ARS, Beltsville, MD), respectively.

Fresh fruit petioles or leaf midribs (1 to $2 \mathrm{~g}$ per sample) were used for DNA extraction from chokecherry plants, whereas leaves were used for DNA extraction from periwinkle plants. Prior to DNA extraction, each sample was rinsed in a $70 \%$ ethanol solution. DNA extraction followed the procedure described by Lee et al. (18) and Guo et al. (13).

PCR amplification. Five primer pairs were used for amplification of the $16 \mathrm{~S}$ 
rRNA gene, 23S rRNA gene, rp genes, and $16 \mathrm{~S} / 23 \mathrm{~S}$ spacer region (Table 2 ). The locations of these primers are shown in Figure 1. Primers were synthesized by Gibco BRL
Inc. (Grand Island, NY). The primer pair $\mathrm{rpF} 1 / \mathrm{R} 1$, amplifying two rp genes ( $r p l 22$ and $r p s 3$ ), and the primer pairs $\mathrm{R} 16 \mathrm{~F} 2 / \mathrm{R} 2$ and R16(III)F2/R1, amplifying the $16 \mathrm{~S}$
Table 1. X-diseased chokecherry samples and the detection of the phytoplasma by polymerase chain reaction (PCR) amplification

\begin{tabular}{lccccc}
\hline & & \multicolumn{5}{c}{ Numbers of positive amplification in PCR } \\
\cline { 3 - 6 } Sites $^{\mathbf{b}}$ & No. of samples & rp & $\mathbf{1 6 S}$ & $\mathbf{1 6 S} / \mathbf{2 3 S}$ spacer & $\mathbf{2 3 S}$ \\
\hline Barnes & 1 & 0 & 0 & 1 & 0 \\
Billings & 1 & 1 & 1 & 1 & 1 \\
Burleigh & 13 & 8 & 8 & 12 & 7 \\
Cass & 1 & 1 & 1 & 1 & 1 \\
Cavalier & 1 & 1 & 1 & 1 & 1 \\
Emmons & 1 & 1 & 1 & 1 & 1 \\
Hubbard & 1 & 1 & 1 & 1 & 0 \\
LaMoure & 1 & 1 & 1 & 1 & 1 \\
Logan & 1 & 0 & 0 & 0 & 1 \\
Martin & 2 & 1 & 1 & 2 & 1 \\
Mckenzie & 1 & 1 & 1 & 1 & 0 \\
McHenry & 1 & 0 & 0 & 0 & 1 \\
Morton & 1 & 0 & 0 & 1 & 0 \\
Mountrail & 1 & 1 & 1 & 1 & 0 \\
Pembina & 1 & 7 & 9 & 10 & 2 \\
Ransom & 1 & 0 & 1 & 1 & 0 \\
Rolette & 1 & 0 & 1 & 1 & 22 \\
Stark & 2 & 2 & 2 & 2 & 1 \\
Ward & 1 & 0 & 1 & 39 & \\
Total & 43 & 26 & 31 & & \\
\hline
\end{tabular}

a Primer sequences are listed in Table 2; rp = ribosomal protein.

b All sites are in North Dakota counties except Hubbard County, MN, and Martin Rural Municipality, Saskatchewan, Canada.
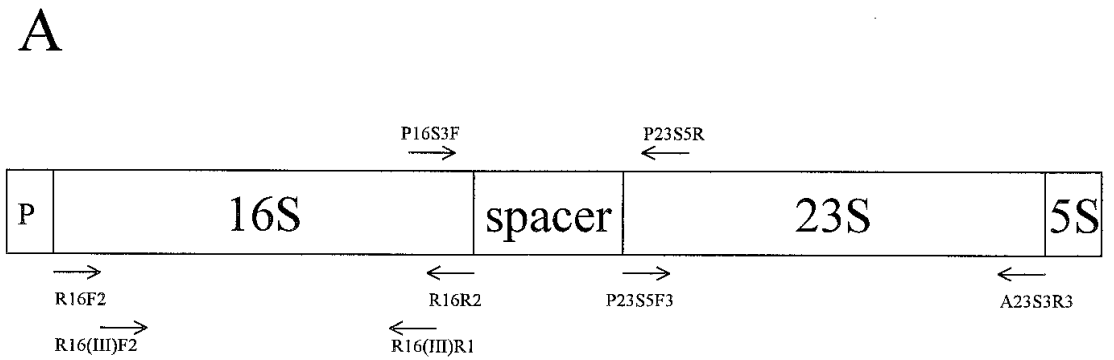

B

\begin{tabular}{c|c|c|c}
\hline $\mathrm{rps} 19$ & $\mathrm{rpl} 22$ & $\mathrm{rps} 3$ & $\mathrm{rpl16}$ \\
\hline$\underset{\mathrm{rpF1}}{\longrightarrow} \underset{\mathrm{rpRI}}{\leftarrow}$
\end{tabular}

Fig. 1. Schematic locations of polymerase chain reaction primers used in this study. (A) rRNA operon. P, promoter; 16S, 23S, and 5S represent 16S rRNA, 23S rRNA, and 5S rRNA genes, respectively. (B) Ribosomal protein genes.
rRNA gene in nested PCR, were designed by Lim and Sears (24) and Lee et al. $(20,21)$, respectively. Nested PCR was used for the 16S rRNA gene amplification because single-step PCR did not reliably result in a visible band $(20,21)$. New primers were developed to allow amplification of additional gene segments that might provide more information regarding population variability (12). Primer pair P23S5F3/A23S3R3 was designed to amplify the phytoplasmal 23S rRNA gene based on the conserved sequences in the ribosomal RNA genes of various Mollicutes (12). Primer pair P16S3F/P23S5R, amplifying the $16 \mathrm{~S} / 23 \mathrm{~S}$ spacer region, was designed for this study on the basis of the rRNA genes of a phytoplasma associated with spartium witches'-broom disease (Genbank accession \#X92869). The forward primer P16S3F and the reverse primer P23S5R sequences corresponded to the positions 1,353 to 1,377 and 1,746 to 1,770 , respectively. The sequence of the amplified fragment was compared with that of the $16 \mathrm{~S} / 23 \mathrm{~S}$ spacer region of $O e$ nothera witches'-broom phytoplasmas (GenBank accession \#M74770), a member of the aster yellows phytoplasma group.

Total nucleic acids extracted from chokecherry and periwinkle plant samples were each used as templates in PCR. Each PCR amplification consisted of $20 \mathrm{ng}$ of total DNA (10 ng if from periwinkle), 1.5 $\mathrm{mM} \mathrm{MgCl}_{2}, 10 \mathrm{mM}$ Tris-HCl (pH 8.0), four dNTPs (200 $\mu \mathrm{M}$ each), primers $(0.2$ pmol each), and 0.125 units of Taq DNA polymerase (Promega Corp., Madison, WI), in a final volume of $25 \mu \mathrm{l}$. The PCR reactions were performed in a thermocycler (RoboCycler Gradient 96; Stratagene, La Jolla, CA) for 35 cycles. The amplification conditions for the rp genes consisted of denaturing for $1 \mathrm{~min}$ at $94^{\circ} \mathrm{C}(2 \mathrm{~min}$ for the first cycle), annealing for $3 \mathrm{~min}$ at $46^{\circ} \mathrm{C}$, and extension for $3 \mathrm{~min}$ at $72^{\circ} \mathrm{C}(10$ min for the final cycle). The same amplification conditions were used for the $16 \mathrm{~S}$ rRNA gene, the 23S rRNA gene, and the $16 \mathrm{~S} / 23 \mathrm{~S}$ spacer region, except that the annealing step was $2 \mathrm{~min}$ at either $50^{\circ} \mathrm{C}$ (16S rDNA) or $60^{\circ} \mathrm{C}$ (spacer region and $23 \mathrm{~S}$ rDNA). For nested PCR, the product amplified by the primer pair R16F2/R2 was diluted 50-fold with distilled water, and $1 \mu \mathrm{l}$ of the diluted solution was used as

Table 2. Sequences and applications of oligonucleotide primer pairs

\begin{tabular}{lllc}
\hline Primer pair & \multicolumn{1}{c}{ Sequence $\left(\mathbf{5}^{\prime} \rightarrow \mathbf{3}^{\prime}\right)$} & \multicolumn{1}{c}{ Primed amplification } & Reference \\
\hline rpF1/R1 & $\begin{array}{l}\text { GGACATAAGTTAGGTGAATTT } \\
\text { ACGATATTTAGTTCTTTTTGG } \\
\text { ACGACTGCTGCTAAGACTGG } \\
\text { R16F2/R2 }\end{array}$ & ribosomal protein genes $(r p l 22$ and $r p s 3)$ & 24 \\
R16(III)F2/R1 & $\begin{array}{l}\text { TAGGGGGGTGTTACAAACCCCG } \\
\text { AAGAGGGAAAAACTCCC }\end{array}$ & 16S rRNA gene (universal) & 21 \\
P16S3F/P23S5R & $\begin{array}{l}\text { TCCGAACTGAGATTGA } \\
\text { CGGGGTTTGTACACACCGCCCGTCA }\end{array}$ & 16S/23S rDNA spacer region & 20 \\
P23S5F3/A23S3R3 & $\begin{array}{l}\text { TCTTAGTGCCAAGGCATCCACTGTC } \\
\text { GTGGATGCCTTGGCACTAAGAGCC }\end{array}$ & $23 \mathrm{~S}$ rRNA gene & This study \\
\hline
\end{tabular}


a template for amplification with the primer pair R16(III)F2/R1. A 5- to $10-\mu \mathrm{l}$ aliquot of product from each PCR was examined by electrophoresis through $1 \%$ agarose gels and by visualization under UV light after staining with $0.5 \mu \mathrm{g}$ of ethidium bromide per milliliter of water.

RFLP analysis. For RFLP analysis of amplified rp, 16S rRNA, and 23S rRNA genes, the PCR products were directly digested with restriction enzymes $A l u \mathrm{I}$, HpaII, MseI, and RsaI in the digestion buffer recommended by the manufacturer (New England Biolabs, Beverly, MA). For each digestion, 2 to 5 units of restriction enzyme were used for 5 to 10 $\mu \mathrm{l}$ of PCR product in a total volume of 20 $\mu \mathrm{l}$. The digestion mixture was incubated at $37^{\circ} \mathrm{C}$ for $4 \mathrm{~h}$. Digested DNA was separated by electrophoresis in a $6 \%$ polyacrylamide gel (Bio-Rad, Hercules, CA) or $2.5 \%$ agarose gel (3:1, wide range-standard agarose, Sigma-Aldrich, St. Louis) in Tris-borate EDTA (TBE) buffer. The polyacrylamide gels were stained using DNA Silver Staining System (Promega Corp.), and the agarose gels using ethidium bromide.

Direct cloning of the PCR product. The PCR-amplified 16S/23S spacer region was cloned into the commercial plasmid vector pPCRII (TA cloning kit; Invitrogen, San Diego, CA) following the manufacturer's recommended protocol. Ligation, transformation, and selection of the recombinant clones were carried out using the manufacturer's recommended protocol. Recombinant plasmid DNA, purified by using a commercial kit (PerfectPrep plasmid DNA Kit, 5 Primer $\rightarrow 3$ Primer, Inc., Boulder, $\mathrm{CO}$ ), was restricted with the enzyme EcoRI and separated in a $0.8 \%$ agarose gel in TBE buffer. The full-length inserts were confirmed by comparing the size of inserts with that of the PCR-amplified spacer region.

Sequencing of the PCR product. The double-stranded plasmid clones were sequenced by a LI-COR (LI-COR, Inc., Lincoln, NE) protocol (sequencing bulletin \#13) using Epicentre SequiTherm LongRead Cycle Sequencing Kits (Epicentre Technologies, Madison, WI). M13 forward and reverse primers labeled with IRD41 fluorescent dye were used as sequencing primers. Sequencing gels were run, and the sequence data were automatically collected with LI-COR DNA Sequencer Model 4000L and sequenced with BASE IMAGIR (version 2.3, LI-COR). One clone of the amplified fragment from each of 12 randomly selected ChX phytoplasma isolates and three clones from both the CX and WX phytoplasma strains were sequenced. Both strands of each clone were sequenced, and the sequencing was repeated at least once. Sequence comparisons were done with a software package, PSININE (Department of Biochemistry, North Dakota State University, Fargo).

\section{RESULTS}

PCR amplification. PCR amplification of the rp, 16S rRNA, and 23S rRNA genes and the $16 \mathrm{~S} / 23 \mathrm{~S}$ spacer region from genomic DNA yielded one fragment of about $1.5,0.8,2.8$, and $0.45 \mathrm{kbp}$, respectively, from $\mathrm{ChX}$ phytoplasma isolates (Fig. 2). Amplification fragments of the same size were obtained from CX, GR1, and WX phytoplasmas. Of 43 chokecherry samples, 26 showed positive amplification for the rp genes, 31 for the 16S rRNA gene, 39 for the $16 \mathrm{~S} / 23 \mathrm{~S}$ spacer region, and 22 for the 23S rRNA gene (Table 1). These gene segments were not amplified during PCR from healthy control plants.

RFLP analysis. Digestion by four restriction enzymes of the amplified rp, 16S rRNA, and 23S rRNA genes provided RFLP profiles (Figs. 3, 4, and 5). Only one sample of ChX phytoplasmas was shown in each gel picture because digestion of the total amplified products with each of the four restriction enzymes gave an identical RFLP profile among all amplified $\mathrm{ChX}$ phytoplasma samples. For the rp genes (Fig. 3), AluI digestion produced identical RFLP patterns among GR1, WX, and ChX phytoplasmas, but it produced one extra band (about $400 \mathrm{bp}$ ) from CX phytoplasmas. Both HpaII and RsaI digestions yielded the same profiles among CX, WX, and $\mathrm{ChX}$ phytoplasmas, but two fewer bands (about $450 \mathrm{bp}$ and $800 \mathrm{bp}$ ) were produced from GR1 phytoplasmas with HpaII, and two additional bands (about $500 \mathrm{bp}$ and $800 \mathrm{bp}$ ) were produced from GR1 phytoplasmas with RsaI. Fragments resulting from the digestion of $M s e I$ were so small that differences could not be accurately interpreted. For RFLP analysis of the 16S rRNA gene (Fig. 4), both AluI and

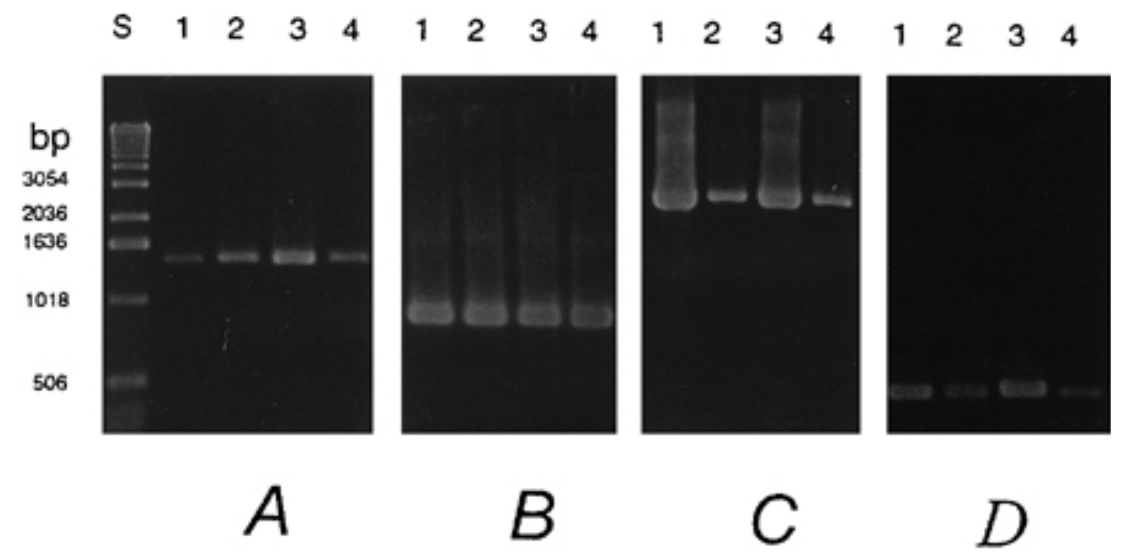

Fig. 2. Ethidium bromide-stained $1 \%$ agarose gels of polymerase chain reaction (PCR)-amplified products from genomic DNA of phytoplasmas. (A) Ribosomal protein genes by primer pair rpF1/R1; (B) 16S rRNA gene by R16F2/R2 and R16(III)F2/R1 in nested PCR; (C) 23S rRNA gene by P23S5F3/A23S3R3; (D) 16S/23S spacer region by P16S3F/P23S5R. Lane designations: S = 1-kb ladder, 1 = eastern X-disease $(\mathrm{CX})$ phytoplasma, 2 = goldenrod yellows (GR1) phytoplasma, $3=$ western X-disease (WX) phytoplasma, 4 = one representative of chokecherry X-disease $(\mathrm{ChX})$ phytoplasma from North Dakota.

\section{$\begin{array}{lllll}S & 1 & 2 & 3 & 4\end{array}$}

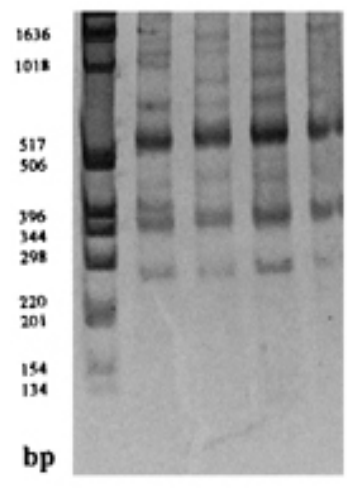

Alu I

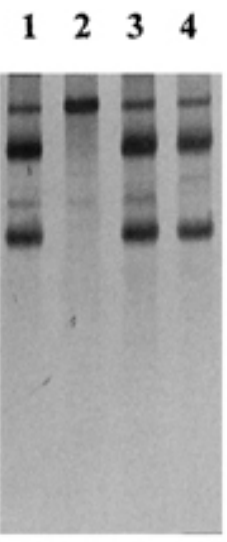

Hpa II

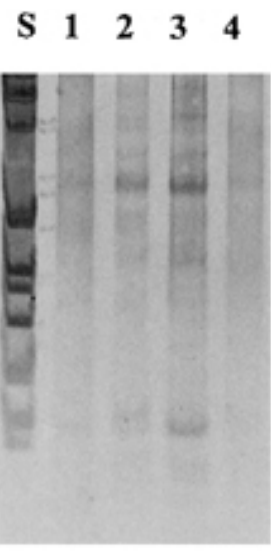

Mse I
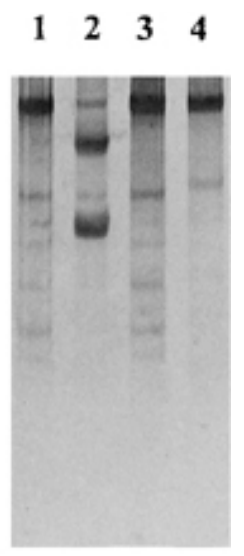

Rsa I

Fig. 3. Restriction fragment length polymorphism (RFLP) profiles of amplified ribosomal protein products by primer pair rpF1/R1 on silver-stained $6 \%$ polyacrylamide gels. Lane designations: $\mathrm{S}=1-\mathrm{kb}$ ladder, 1 = eastern X-disease $(\mathrm{CX})$ phytoplasma, 2 = goldenrod yellows $(\mathrm{GR} 1)$ phytoplasma, 3 = western X-disease (WX) phytoplasma, $4=$ one representative of chokecherry X-disease (ChX) phytoplasma from North Dakota. AluI, HpaII, MseI, and RsaI are the restriction enzymes used to obtain RFLPs. 
RsaI digestions produced identical profiles among CX, GR1, WX, and ChX phytoplasmas. HpaII and MseI digestions produced distinguishable RFLP patterns between GR1 and the other three phytoplasmas (additional fragments of about 300 bp and $500 \mathrm{bp}$ for HpaII and missing a fragment of about $150 \mathrm{bp}$ for MseI from GR1 phytoplasmas). For RFLP analysis of the 23S rRNA gene, CX, GR1, WX, and ChX phytoplasmas showed the same RFLP profiles from each of four enzyme digestions (Fig. 5). Overall, RFLP patterns with all four enzymes were the same between $\mathrm{ChX}$ and WX phytoplasmas, one band differed between $\mathrm{ChX}$ and $\mathrm{CX}$ phytoplasmas, and eight bands differed between ChX and GR1.

Comparison of the $16 \mathrm{~S} / 23 \mathrm{~S}$ rRNA spacer region sequence. Using the primer pair P16S3F/P23S5R, a single fragment was amplified from CX, GR1, WX, and ChX phytoplasmas (Fig. 2D). The sequences within $\mathrm{CX}$ and within WX phytoplasma isolates were identical among repeated samples. The fragment sequence from a representative $\mathrm{ChX}$ phytoplasma isolate covered the $3^{\prime}$ end of the $16 \mathrm{~S}$ rRNA gene, the $16 \mathrm{~S} / 23 \mathrm{~S}$ spacer region, and the $5^{\prime}$ end of the 23S rRNA gene (Fig. 6). The amplified products ranged from 439 to 441 bp for ChX phytoplasmas, and were 439 and 440 bp for CX and WX phytoplasmas, respectively. By comparing the $16 \mathrm{~S} / 23 \mathrm{~S}$ spacer region sequence of Oenothera witches'-broom phytoplasmas (22), a conserved sequence coding for a tRNA $^{\text {Ile }}$ (bases 239 to 320 ) and a sequence implicated in rRNA processing (bases 361 to 380) were identified from the spacer regions of ChX phytoplasmas (Fig. 6). A comparison among sequences from 12 ChX phytoplasma isolates collected from North Dakota and from CX and WX phytoplasmas is shown in Table 3. Among all isolates sequenced, there were six locations with base substitutions or deletions. Except for one in WX phytoplasmas, all base changes occurred outside of the two conserved sequences. Of $12 \mathrm{ChX}$ phytoplasma isolates, 7 had identical sequences with a fragment size of $441 \mathrm{bp}, 2$ exhibited one base substitution, 1 had one base deletion, and 2 had two base deletions (Table 3 ).

In comparing $\mathrm{ChX}$ phytoplasmas with CX and WX phytoplasmas, the number of variable bases compared with CX phytoplasmas ranged from one to three, and with WX phytoplasmas from four to six. Each base in the variable positions of the $\mathrm{CX}$ ChX phytoplasma isolates. Three substitutions in these positions in the WX phytoplasma isolate were not present among the $\mathrm{ChX}$ phytoplasma isolates.

\section{DISCUSSION}

Recent advents in molecular biology have allowed partial characterization of phytoplasmas at the molecular level $(2,29)$. phytoplasma isolate was present among the

With PCR technology, the 16S rRNA gene can be amplified from phytoplasmas by using primers heterologous to the gene sequence from related organisms, such as acholeplasmas and mycoplasmas (5). RFLP analysis of the amplified 16S rRNA gene and, sometimes, direct sequencing of the gene have been extensively used to detect, identify, and classify phytoplasmas and to determine phylogenic relationships (1,4-6,13,17,20,21,26,27,29).

In comparison with information regarding variation in phytoplasmas among the groups, information about genetic variation within a phytoplasma group or subgroup is limited. Based on RFLP profiles of the 16S rRNA gene and the ribosomal protein genes from three isolates, $\mathrm{X}$-disease phytoplasmas from chokecherry plants in the north-central United States have been previously reported as closely related to $\mathrm{CX}$ and WX phytoplasmas (11). In that work,
S $1 \begin{array}{llll}1 & 2 & 3 & 4\end{array}$

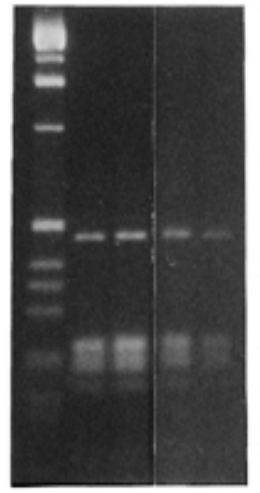

S $\begin{array}{llll}1 & 2 & 3 & 4\end{array}$

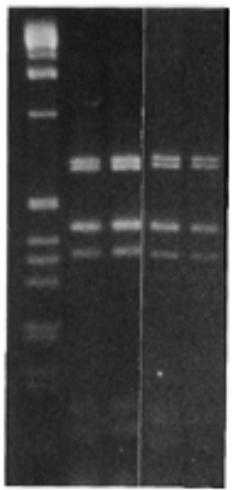

\section{Rsa I \\ Alu I \\ Hpa II \\ Mse I}

Fig. 5. Restriction fragment length polymorphism (RFLP) profiles of amplified 23S rRNA products by primer pair $\mathrm{P} 23 \mathrm{~S} 5 \mathrm{~F} 3 / \mathrm{A} 23 \mathrm{~S} 3 \mathrm{R} 3$ on ethidium bromide-stained $2.5 \%$ agarose gels. Lane designations: $\mathrm{S}=1$-kb ladder, 1 = eastern X-disease $(\mathrm{CX})$ phytoplasma, $2=$ goldenrod yellows (GR1) phytoplasma, 3 = western X-disease (WX) phytoplasma, 4 = one representative of chokecherry X-disease $(\mathrm{ChX})$ phytoplasma from North Dakota.

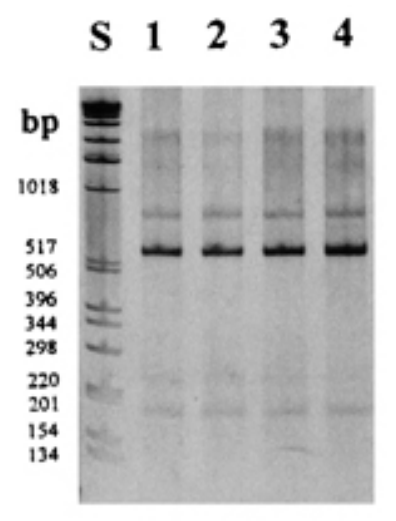

Alu I

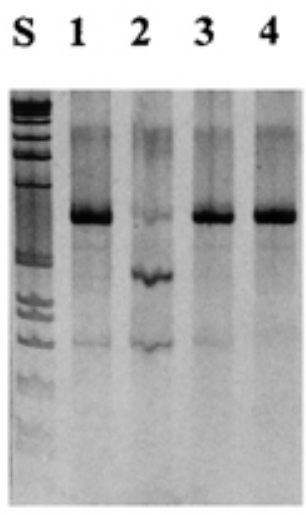

Hpa II

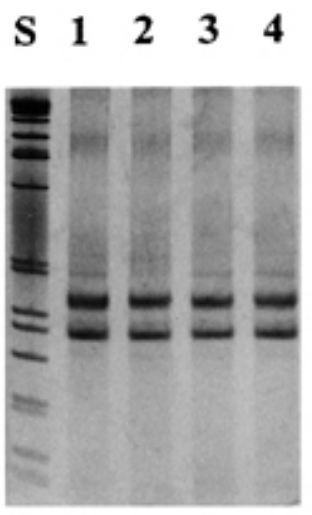

Rsa I

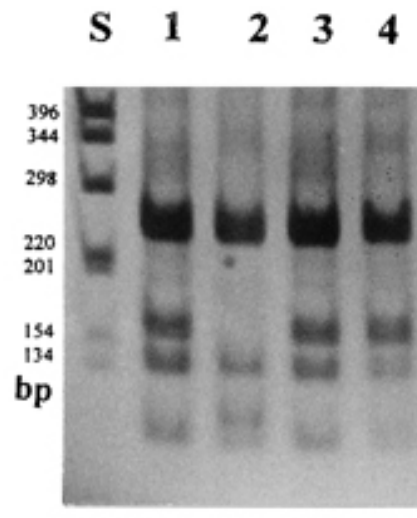

Mse I

Fig. 4. Restriction fragment length polymorphism (RFLP) profiles of amplified 16S rRNA products by primer pairs R16F2/R2 and R16(III)F2/R1 on silver-stained $6 \%$ polyacrylamide gels. Lane designations: $\mathrm{S}=1$-kb ladder, 1 = eastern X-disease $(\mathrm{CX})$ phytoplasma, $2=$ goldenrod yellows (GR1) phytoplasma, 3 = western X-disease (WX) phytoplasma, 4 = one representative of chokecherry X-disease $(\mathrm{ChX})$ phytoplasma from North Dakota. 
ChX phytoplasmas from New York and North Dakota were grouped with CX and WX phytoplasmas into a single $16 \mathrm{~S}$ rRNA subgroup (16SrIII-A), and the GR1 phytoplasma isolate was placed in a different subgroup (16SrIII-D). Also in that work, CX phytoplasmas were placed in subgroup 16SrIII-A(rp), and WX and ChX phytoplasmas were placed in subgroup 16SrIII$\mathrm{B}(\mathrm{rp})$, whereas GR1 phytoplasmas were placed in subgroup 16SrIII-E(rp). Even though some of the restriction enzymes were different, results of our RFLP analyses support the subgrouping by Gundersen et al. (11) using the 16S rRNA gene (ChX, $\mathrm{WX}$, and CX phytoplasmas are in one subgroup, GR1 phytoplasmas are in another subgroup) and rp genes (ChX and WX phytoplasmas are in one subgroup, CX phytoplasmas in another subgroup, and GR1 phytoplasmas in a third subgroup). Both studies indicated that CX, WX, and ChX phytoplasmas are closely related, whereas GR1 phytoplasmas are related, but substantially different than those that were isolated from Prunus spp.

RFLP profiles of the $16 \mathrm{~S}$ rRNA gene and of $\mathrm{rp}$ genes showed no variation among all $43 \mathrm{ChX}$ phytoplasma isolates and few variations between $\mathrm{ChX}, \mathrm{CX}$, and WX phytoplasmas. In order to further evaluate the amount of variation, we designed primer pairs to amplify the $23 \mathrm{~S}$ rRNA gene and the $16 \mathrm{~S} / 23 \mathrm{~S}$ spacer region. The 23S rRNA gene is twice as long as the $16 \mathrm{~S}$ rRNA gene; therefore, we expected to detect more variation with RFLP analysis. However, we found even less variation in the 23S rRNA gene than in the 16S rRNA gene among $\mathrm{ChX}, \mathrm{CX}, \mathrm{WX}$, and GR1 phytoplasmas. An identical RFLP profile was produced for each phytoplasma with the four tested restriction enzymes.

Because of high conservation of rRNA genes, the intergenic spacer region between rRNA genes, which is considered to be a variable region $(2,14,22)$, has been widely used to differentiate relatively closely re- lated organisms. Smart et al. (32) found relatively high variation in the spacer region among different phytoplasma groups. In our research, sequence variation in the spacer region indicated four subgroups among $12 \mathrm{ChX}$ phytoplasma isolates, whereas no variation had been found using RFLP analysis of 16S rRNA, 23S rRNA, and two rp genes of $43 \mathrm{ChX}$ isolates. The sequence variations were very likely true variations, not errors in gene amplification or sequencing, because seven ChX phytoplasma isolates showed identical sequences, and repeated sequencing of the $16 \mathrm{~S} / 23 \mathrm{~S}$ spacer region within CX and WX phytoplasma isolates were also identical. The variable bases, however, represent only about $1.4 \%(6 / 441)$ of the spacer region sequence. This is probably due to two highly conserved sequences, the tRNA ${ }^{\text {Ile }}$ sequence and a sequence implicated in rRNA processing (23).

It is difficult to compare the level of variability of $\mathrm{ChX}$ phytoplasmas found in this study with that in other phytoplasmas because there is relatively little directly comparable information in the literature. Using more RFLP restriction enzymes with fewer genes and fewer phytoplasma iso- lates from a wider geographic range, Griffiths et al. $(8,9)$ found RFLP and sequencing variation within regions in elm yellows phytoplasmas, but not within regions in ash yellows phytoplasmas. We found no RFLP variation among $\mathrm{ChX}$ phytoplasma isolates in the region, but there were sequencing variations. Only a limited portion of the genome, such as the rp, rRNA gene, and elongation factor genes (3) and the $16 \mathrm{~S} / 23 \mathrm{~S}$ spacer region, has been available to study phytoplasmas. All of these regions show a high degree of conservation within phytoplasma subgroups; therefore, other parts of the genome must be explored to identify regions that may exhibit more dramatic variation and more clearly delineate the relatedness of phytoplasmas. Lee et al. (19) found a greater difference than we found between CX and WX phytoplasmas by hybridization employing randomly cloned chromosomal fragments as probes. Unfortunately, little is known about the sequences and functions of these probe fragments.

Our sequencing data indicated that $\mathrm{ChX}$ phytoplasmas are substantially more similar to CX than to WX phytoplasmas. This

Table 3. $16 \mathrm{~S} / 23 \mathrm{~S}$ spacer region sequence variation between X-disease phytoplasma isolates collected from chokecherry plants in North Dakota $(\mathrm{ChX})$ and standard strains of eastern X-disease (CX) and western X-disease (WX) phytoplasmas

\begin{tabular}{|c|c|c|c|c|c|c|c|c|}
\hline \multirow[b]{2}{*}{ Phytoplasmas } & \multicolumn{2}{|c|}{ No. compared to } & \multicolumn{6}{|c|}{ Locations of variable bases ${ }^{b}$} \\
\hline & CX & WX & 32 & 37 & 91 & 142 & 330 & 373 \\
\hline \multicolumn{9}{|l|}{ ChX isolates ${ }^{c}$} \\
\hline $1-7$ & 2 & 5 & G & A & A & $\mathrm{G}$ & $\mathrm{T}$ & $\mathrm{T}$ \\
\hline 8,12 & 3 & 4 & $\mathrm{G}$ & $\mathrm{T}$ & A & $\mathrm{G}$ & $\mathrm{T}$ & $\mathrm{T}$ \\
\hline 9 & 1 & 6 & $\mathrm{G}$ & A & A & - & $\mathrm{T}$ & $\mathrm{T}$ \\
\hline 10,11 & 2 & 4 & G & A & - & G & - & $\mathrm{T}$ \\
\hline CX & $\ldots$ & 6 & G & A & A & - & - & $\mathrm{T}$ \\
\hline WX & 6 & $\ldots$ & A & $\mathrm{T}$ & - & G & A & A \\
\hline
\end{tabular}

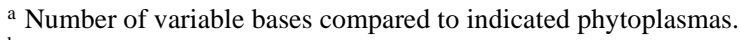

${ }^{\mathrm{b}}$ Base number is based on the sequence numbering in Figure 6; - indicates base deletion in the position.

${ }^{\mathrm{c}} \mathrm{ChX}$ isolate 1 from Cass county; isolates 2 to 8 from Burleigh county; isolates 9 to 12 from Pembina county

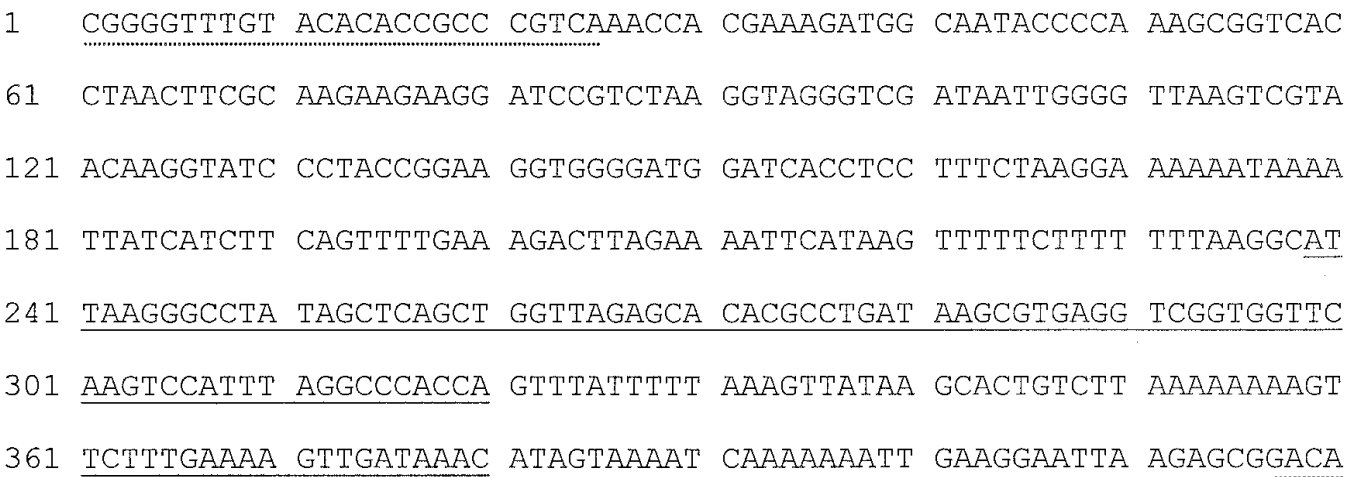

421 GTGGATGCCT TGGCAATAAG A

Fig. 6. 16S/23S spacer region sequence of the X-disease phytoplasma (chokecherry isolate 2, Burleigh Co.). Underlined sequences represent a conserved tRNA ${ }^{\text {Ile }}$ sequence (bases 239 to 320) and a highly conserved sequence implicated in rRNA processing (bases 361 to 380), respectively. Forward primer P16S3F sequence (bases 1 to 25) and reverse primer P23S5R sequence (bases 417 to 441) are indicated with dash lines. 
result is the reverse of results indicated by RFLP analysis. Together, the results indicate that $\mathrm{X}$-disease phytoplasmas from chokecherry in central North America are genetically different from CX and WX phytoplasmas. This distinction may reflect geographic or vector isolation, or specialization over time of another X-disease strain to the hosts or environmental conditions of this region.

\section{ACKNOWLEDGMENTS}

We thank W. Sargent for technical assistance; S. Horne (Department of Microbiology and Veterinary Sciences at North Dakota State University) for assistance in DNA sequencing; and T. A. Chen (Rutgers University, New Brunswick, NJ), W. A. Sinclair (Cornell University, Ithaca, NY), and I.M. Lee (USDA-ARS, Beltsville, MD) for providing experimental phytoplasmas.

\section{LITERATURE CITED}

1. Ahrens, U., and Seemuller, E. 1992. Detection of DNA of plant pathogenic mycoplasmalike organisms by a polymerase chain reaction that amplifies a sequence of the 16S rRNA gene. Phytopathology 82:828-832.

2. Barry, T., Colleran, G., Glennon, M., Dunican, L. K., and Gannon, F. 1991. The 16S/23S ribosomal spacer region as a target for DNA probes to identify eubacteria. PCR Methods Appl. 1:51-56.

3. Berg, M., and Seemuller, E. 1999. Chromosomal organization and nucleotide sequence of the genes coding for the elongation factors $\mathrm{G}$ and $\mathrm{Tu}$ of the apple proliferation phytoplasma. Gene 226:103-109.

4. Davis, R. E., and Lee, I.-M. 1993. Clusterspecific polymerase chain reaction amplification of 16S rDNA sequences for detection and identification of mycoplasmalike organisms. Phytopathology 83:1008-1011.

5. Deng, S., and Hiruki, C. 1991. Amplification of 16S rRNA genes from culturable and nonculturable mollicutes. J. Microbiol. Methods 14:53-61.

6. Firrao, G., Gobbi, E., and Locci, R. 1993. Use of polymerase chain reaction to produce oligonucleotide probes for mycoplasmalike organisms. Phytopathology 83:602-607.

7. Gilmer, R. M., Moore, J. D., and Keitt, G. W. 1954. X-disease virus: I. Host range and pathogenesis in chokecherry. Phytopathology 44:180-185.

8. Griffiths, H. M., Sinclair, W. A., BoudonPadieu, E., Daire, X., Lee, I.-M., Sfalanga, A., and Bertaccini, A. 1999. Phytoplasmas associated with elm yellows: Molecular variability and differentiation from related organisms. Plant Dis. 83:1101-1104.

9. Griffiths, H. M., Sinclair, W. A., Smart, C. D., and Davis, R. E. 1999. The phytoplasma asso- ciated with ash yellows and lilac witches'broom: 'Candidatus' Phytoplasma fraxini. Int. J. Sys. Bacteriol. 49:1605-1614.

10. Gundersen, D. E., Lee, I.-M., Rehner, S. A., Davis, R. E., and Kingsbury, D. T. 1994. Phylogeny of mycoplasmalike organisms (phytoplasmas): A basis for their classification. J. Bacteriol. 176:5244-5254.

11. Gundersen, D. E., Lee, I-M., Schaff, D. A., Harrison, N. A., Chang, C. J., Davis, R. E., and Kingsbury, D. T. 1996. Genomic diversity and differentiation among phytoplasma strains in 16S rRNA groups I (aster yellows and related phytoplasmas) and III (X-disease and related phytoplasmas). Int. J. Syst. Bacteriol. 46:64-75.

12. Guo, Y. H., Cheng, Z.-M., and Walla, J. A. 2000. Amplification of the $23 \mathrm{~S}$ rRNA gene and its application in differentiation and detection of phytoplasmas. Can. J. Plant Pathol. In press.

13. Guo, Y. H., Walla, J. A., Cheng, Z.-M., and Lee, I.-M. 1996. X-disease confirmation and distribution in chokecherry in North Dakota. Plant Dis. 80:95-102.

14. Harasawa, R., Mizusawa, H., Nozawa, K., Nakagawa, T., Asada, K., and Kato, I. 1993. Detection and tentative identification of dominant mycoplasma species in cell cultures by restriction analysis of the $16 \mathrm{~S}-23 \mathrm{~S}$ rRNA intergenic spacer regions. Res. Microbiol. 144:489-493.

15. Jiang, Y. P., Chen, T. A., Chiykowski, L. N., and Sinha, R. C. 1989. Production of monoclonal antibodies to peach eastern X-disease agent and their use in disease detection. Can. J. Plant Pathol. 11:325-331.

16. Kirkpatrick, B. C., Stenger, D. C., Morris, T. J., and Purcell, A. H. 1987. Cloning and detection of DNA from a nonculturable plant pathogenic mycoplasma-like organism. Science 238:197-200.

17. Kuske, C. R., and Kirkpatrick, B. C. 1992. Phylogenetic relationships between the western aster yellows mycoplasmalike organism and other prokaryotes established by $16 \mathrm{~S}$ rRNA gene sequence. Int. J. Syst. Bacteriol. 42:226-233.

18. Lee, I.-M., Davis, R. E., Sinclair, W. A., DeWitt, N. D., and Conti, M. 1993. Genetic relatedness of mycoplasmalike organisms detected in Ulmus spp. in the United States and Italy by means of DNA probes and polymerase chain reactions. Phytopathology 83:829-833.

19. Lee, I.-M., Gundersen, D. E., Davis, R. E., and Chiykowski, L. N. 1992. Identification and analysis of a genomic strain cluster of mycoplasmalike organism associated with Canadian peach (eastern) $\mathrm{X}$ disease, western $\mathrm{X}$ disease, and clover yellow edge. J. Bacteriol. 174:6694-6698.

20. Lee, I.-M., Gundersen, D. E., Hammond, R. W., and Davis, R. E. 1994. Use of mycoplasmalike organism (MLO) group-specific oli- gonucleotide primers for nested-PCR assays to detect mixed-MLO infections in a single host plant. Phytopathology 84:559-566.

21. Lee, I.-M., Hammond, R. W., Davis, R. E., and Gundersen, D. E. 1993. Universal amplification and analysis of pathogen $16 \mathrm{~S}$ rDNA for classification and identification of mycoplasmalike organisms. Phytopathology 83:834-842.

22. Li, X., and De Boer, S. H. 1995. Selection of polymerase chain reaction primers from an RNA intergenic spacer region for specific detection of Clavibacter michiganensis subsp. sepedonicus. Phytopathology 85:837-842.

23. Lim, P. O., and Sears, B. B. 1989. 16S rRNA sequence indicates that plant-pathogenic mycoplasmalike organisms are evolutionarily distinct from animal mycoplasmas. J. Bacteriol. 171:5901-5906.

24. Lim, P. O., and Sears, B. B. 1992. Evolutionary relationships of a plant-pathogenic mycoplasmalike organism and Acholeplasma laidlawii deduced from two ribosomal protein gene sequences. J. Bacteriol. 174:2606-2611.

25. Lin, C. P., and Chen, T. A. 1985. Monoclonal antibodies against the aster yellows agent. Science 227:1233-1235.

26. Lorenz, K.-H., Schneider, B., Ahrens, U., and Seemuller, E. 1995. Detection of the apple proliferation and pear decline phytoplasmas by PCR amplification of ribosomal and nonribosomal DNA. Phytopathology 85:771-776.

27. Namba, S., Oyaizu, H., Kato, S., Iwanami, S., and Tsuchizaki, T. 1993. Phylogenetic diversity of phytopathogenic mycoplasmalike organisms. Int. J. Syst. Bacteriol. 43:461-467.

28. Rosenberger, D. A., and Jones, A. L. 1978. Leafhopper vectors of the peach X-disease pathogen and its seasonal transmission from chokecherry. Phytopathology 68:782-790.

29. Seemuller, E., Schneider, B., Maurer, R., Ahrens, U., Daire, X., Kison, H., Lorenz, K. H., Firrao, G., Avinent, L., Sears, B. B., and Stackebrandt, E. 1994. Phylogenetic classification of phytopathogenic mollicutes by sequence analysis of $16 \mathrm{~S}$ ribosomal DNA. Int. J. Syst. Bacteriol. 44:440-446.

30. Sinclair, W. A., and Griffiths, H. M. 2000 Variation in aggressiveness of ash yellows phytoplasmas. Plant Dis. 84:282-288.

31. Sinclair, W. A., Whitlow, T. H., and Griffiths, H. M. 1997. Heritable tolerance of phytoplasmal infection in green ash. Can. J. For Res. 27:1928-1935.

32. Smart, C. D., Schneider, B., Blomquist, C. L. Guerra, L. J., Harrison, N. A., Ahrens, U., Lorenz, K. H., Seemuller, E., and Kirkpatrick, B. C. 1996. Phytoplasma-specific PCR primers based on sequences of the 16S-23S rRNA spacer region. Appl. Environ. Microbiol. 62:2988-2993.

33. Suslow, K. G., and Purcell, A. H. 1982. Seasonal transmission of $\mathrm{X}$-disease agent from cherry by leafhopper Colladonus montanus. Plant Dis. 66:28-30. 